Perspective

For reprint orders, please contact: reprints@futuremedicine.com

\title{
The biology of glucagon and the consequences of hyperglucagonemia
}

The proglucagon-derived peptide hormone, glucagon, comprises 29 amino acids. Its secretion from the pancreatic $\alpha$ cells is regulated by several factors. Glucagon increases blood glucose levels through gluconeogenesis and glycogenolysis. Elevated plasma concentrations of glucagon, hyperglucagonemia, may contribute to diabetes. However, hyperglucagonemia is also observed in other clinical conditions than diabetes, including nonalcoholic fatty liver disease, glucagon-producing tumors and after gastric bypass surgery. Here, we review the current literature on hyperglucagonemia in disease with a particular focus on diabetes, and finally speculate that the primary physiological importance of glucagon may not reside in glucose homeostasis but in regulation of amino acid metabolism exerted via a hitherto unrecognized hepatopancreatic feedback loop.

First draft submitted: 30 March 2016; Accepted for publication: 26 May 2016; Published online: 9 September 2016

Keywords: diabetes $\bullet$ glucagon $\bullet$ hyperglucagonemia $\bullet$ proglucagon

The peptide hormone glucagon, contributes to the maintenance of euglycemia in humans by increasing hepatic glucose production during fasting by stimulation of glycogenolysis and gluconeogenesis [1]. Elevated plasma concentrations of glucagon (termed hyperglucagonemia) [2] and insufficient secretion of insulin [3] are biochemical hallmarks of diabetes, and the importance of these for the diabetic state is often referred to as the bihormonal hypothesis. Here, we provide an update on the current literature regarding hyperglucagonemia-related diabetes and present some novel perspectives regarding glucagon biology.

\section{A short historical perspective on glucagon}

The history of glucagon began in the early 1920s when Kimball and Murlin reported evidence of a circulating factor with an effect on glucose homeostasis opposite to that of insulin [4]. The glycogenolytic, gluconeo- genic and ketogenic effects of glucagon were first demonstrated in dogs [5]. Eventually, glucagon was purified and sequenced at Eli Lilly (IN, USA), and shortly after, glucagon was made commercially available by the company for treatment of insulin-induced hypoglycemia. Nevertheless, glucagon was first recognized as a hormone after the development of the glucagon radioimmunoassay in 1959 by Roger Unger and colleagues based on the pioneering work by Berson and Yalow [6]; this assay had an instrumental role in the development of the bihormonal hypotheses [7].

The importance of glucagon for hepatic glucose production in vivo was elucidated by blocking the secretion of endogenous glucagon and insulin (by so-called pancreatic clamping with somatostatin) while infusing glucagon at various rates [8]. These experiments clearly demonstrated that hepatic glucose production was regulated in a push-pull manner by both insulin and glucagon, and
Nicolai J Wewer Albrechtsen ${ }^{1,2}$, Rune E Kuhre ${ }^{1,2}$, Jens

Pedersen ${ }^{1,2}$, Filip K Knop ${ }^{1,2,3}$

\& Jens J Holst ${ }^{*, 1,2}$

'Department of Biomedical Sciences, Faculty of Health \& Medical Sciences, University of Copenhagen, Denmark ${ }^{2}$ Novo Nordisk Foundation Center for Basic Metabolic Research, Faculty of Health \& Medical Sciences, University of Copenhagen, Denmark

${ }^{3}$ Center for Diabetes Research, Gentofte Hospital, University of Copenhagen, Hellerup, Denmark

*Author for correspondence:

Tel.: +453532 7518

jjholst@sund.ku.dk
Future $\because$ Medicine part of 
that the endogenous glucose production in the fasting state represents a balance between the stimulatory effects of glucagon and the inhibitory effects of insulin. From experiments involving selective glucagon infusions it became clear that the stimulation of hepatic glucose production under such conditions is evanescent. Several mechanisms may be responsible for this, most importantly upregulation of insulin secretion both by glucagon (which powerfully stimulates insulin secretion [9]) and by hyperglycemia, which then (by over-ruling the effect of glucagon) lowers hepatic glucose production again [10]. Because of the importance of glucagon for regulation of hepatic glucose production, it has been debated whether diabetic hyperglycemia (both in Type 1 diabetes and in Type 2 diabetes) which is at least partly due to increased hepatic glucose production, develops due to insulin deficiency alone (the insulinocentric hypothesis [11]) or whether hypersecretion of glucagon from pancreatic $\alpha$ cells is equally (the bihormonal hypothesis) or even more important (the glucagonocentric hypothesis [7]). In support of a role for glucagon, inhibition of the secretion or action of glucagon has long been an appealing strategy for diabetes treatment $[12,13]$.

\section{Structure of the glucagon molecule, regulation of glucagon secretion $\&$ extrahepatic effects}

Bioactive glucagon is produced by enzymatic cleavage of the proglucagon precursor by prohormoneconvertase 2 (PC2) to form fully processed glucagon of 29 amino acids (Figure 1). Glucagon is secreted from pancreatic $\alpha$ cells in response to falling concentrations of glucose (hypoglycemia, e.g., during aerobic exercise or long-term fasting) or increasing concentrations of amino acids [14] whereas lipids have modest effects on the $\alpha$ cells [15]. Its secretion is also modulated by the intestinal peptides, GLP-1 (inhibits) [16], oxyntomodulin (enhances) [17] and glucose-dependent insulinotropic polypeptide (GIP; enhances) [18,19]. Also the autonomic nervous system may play an important role in regulation of glucagon secretion [20]. The inhibitory action of GLP-1 is currently being exploited in the socalled GLP-1-based therapies [21], which include both GLP-1RAs and inhibitors of the GLP-1-inactivating enzyme, DPP-4, which prolong its survival in the circulation and elevates plasma levels of endogenous, active GLP-1 [22]. In addition to the complexity of stimulatory and inhibitory extrapancreatic factors, glucagon secretion is also regulated by intra-islet factors (paracrine regulation) (Figure 2) [23,24], the secretion of which may, in turn, depend on stimulation by gut-derived hormones and/or neural signals; these signals include somatostatin (from $\delta$ cells) and pos- sibly amylin, insulin, $\gamma$-aminobutyric acid and zinc (from $\beta$ cells) [24]. It remains unclear whether glucagon feedback to $\alpha$ cells in an autocrine manner; according to the most recent studies, $\alpha$ cells do not appear to express glucagon receptors (GCGRs) [25]. As mentioned, glucagon stimulates insulin secretion and may in this way, regulate its own secretion via insulin receptors expressed on the $\alpha$ cells [26]. However, insulin arriving via the arterial supply to the $\alpha$ cells may also directly influence (inhibit) glucagon secretion [27]. Current data suggest that glucagon-induced insulin secretion depends on its cognate receptor but in addition also involves the GLP-1R - both expressed on the pancreatic $\beta$ cells [28,29].

Apart from the liver, glucagon has additional extrapancreatic effects. Thus, large pharmacological doses of glucagon inhibit appetite in humans, but the mechanism involved is unknown (and could involve the GLP-1R). Combined agonists of GCGR and GLP-1R (dual-agonists) are currently being investigated for treating obesity [31]. It has also been suggested that the body weight lowering effects of glucagon are linked to increased hepatic secretion of FGF-21 [32], which in turn may regulate sugar intake, possibly through direct effects on the hypothalamus (as FGF-21 has been detected in human cerebrospinal fluid) [33,34]. Finally glucagon may also have effects on the heart (positive inotropic and chronotropic effects) [35] and gastrointestinal motility (inhibitory) [36] at least when given exogenously at high concentrations.

In summary, regulation of glucagon secretion is complicated, and several in-depth reviews dealing with this have appeared [21,24,37-38]. In the following, we will discuss essential aspects of glucagon measurement in humans.

\section{The measurement of glucagon is tricky but crucial for understanding the biology of glucagon}

A biomarker of disease should only be used if its measurement fulfills the reliability criteria of Richterich (sensitivity, specificity, precision and accuracy [39]) and the standard protocols from the Clinical and Laboratory Standards Institute [40].

The entire amino acid glucagon sequence (HSQGTFTSDYSKYLDSRRAQDFVQWLMNT) is also found in the two peptide hormones, oxyntomodulin and glicentin, which are secreted from intestinal L-cells in response to nutrient intake [30]. However, both of these peptides are C-terminally elongated compared with native glucagon; thus, antibodies binding to the free C-terminus of the glucagon molecule are in principle specific for pancreatic glucagon (Figure 1). Extrapancreatic glucagon secretion has been reported after 


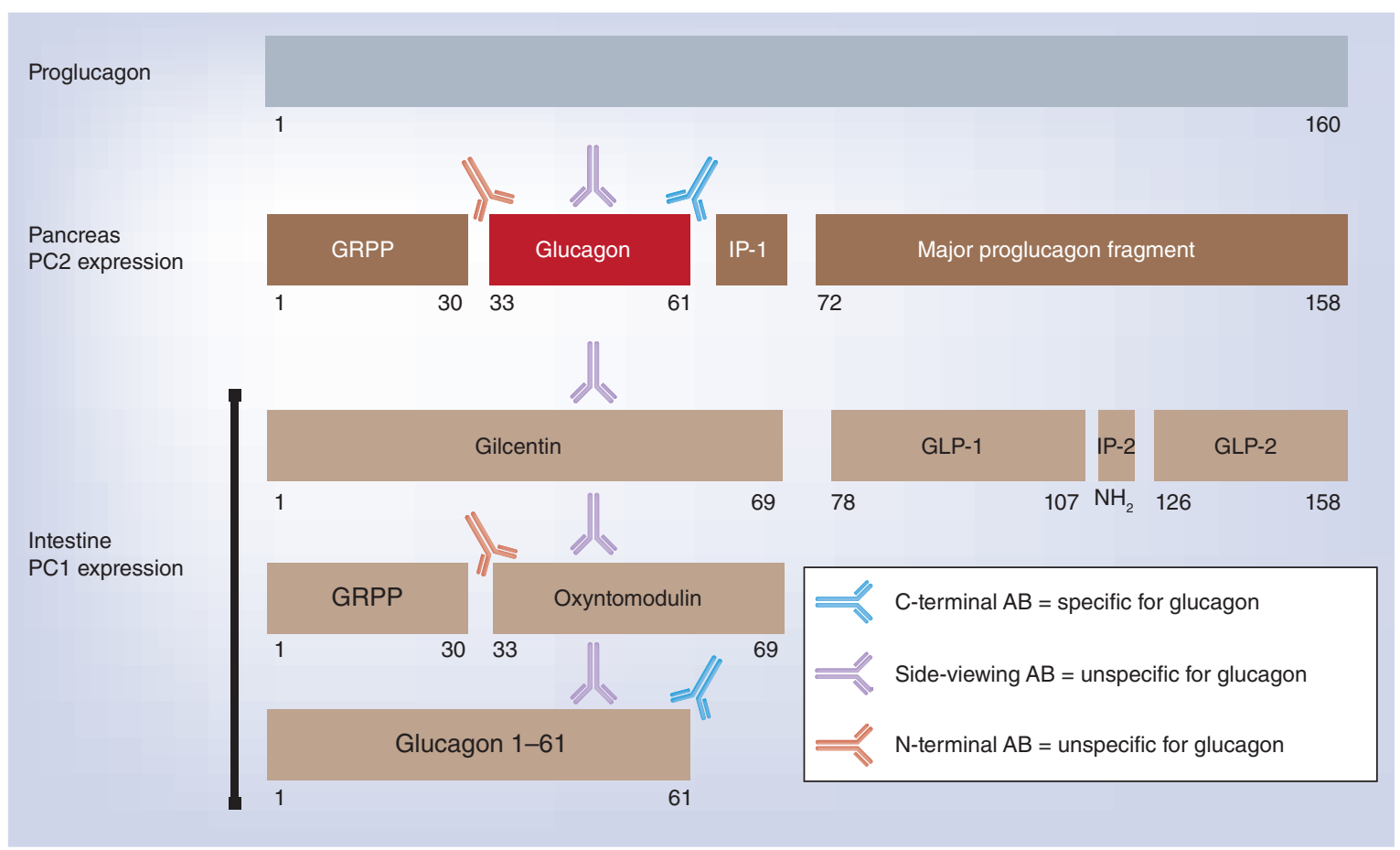

Figure 1. Molecular processing of proglucagon to glucagon in humans and immuno-based methods for detection. Glucagon (33-61) results from prohormone convertase 2-dependent processing of proglucagon (1-160). In the intestine, proglucagon is processed by PC1/3 activity to glicentin (1-69), which may be further cleaved into GRPP and oxyntomodulin (33-69). Due to these processing patterns, immune-based methods relying on a single antibody will not be specific for glucagon: antibodies raised against the $\mathrm{N}$-terminal region will cross-react with oxyntomodulin, C-terminal antibodies with proglucagon 1-61, and 'side-viewing' antibodies will bind to glucagon, glicentin, oxyntomodulin and glucagon 1-61. Full specificity requires a 'sandwich' approach, involving a combination of $\mathrm{N}$ - and C-terminally directed antibodies.

Data taken with permission from [30].

GRPP: Glucagon-reactive polypeptide.

pancreatectomy in humans [41] (and in dogs [42]) using $\mathrm{C}$-terminal glucagon assays that were subsequently validated using state-of-the-art MS [43]. In addition, a molecule with a molecular weight similar to that of pancreatic glucagon (3485 MW) has been reported to be produced in the GI tract of several species [44]. Thus, there is little doubt that fully processed glucagon may be secreted from extrapancreatic sites in humans, at least under certain circumstances.

Significant presence in the circulation of N-terminally elongated glucagon (proglucagon 1-61) has been reported in patients with kidney failure; thus, glucagon measurements in subjects with impaired kidney function may lead to overestimation of endogenous glucagon secretion [45]. The stability of the glucagon molecule and the sensitivity of the assay must be considered when designing studies and planning measurements of endogenous glucagon in humans, as discussed elsewhere in detail [45-48].

\section{Hyperglucagonemia \& diabetes: head or toe?}

The importance of glucagon in normal glucose homeostasis and in the pathogenesis of diabetes remains intensely debated [7,31]. Hyperglucagonemia is observed in most, but not all, subjects with Type 2 diabetes during fasting [49-51]. However, an initial lack of suppression or hypersecretion of glucagon during a carbohydrate-rich meal is always reported [52], and this has been suggested to indicate that the $\alpha$ cell response to hyperglycemia is blunted, but the mechanism underlying this effect has not been clarified [53]. Thus, an isoglycemic intravenous glucose infusion (i.e., resulting in identical glucose concentrations as the oral administration) typically inhibits glucagon secretion in an almost normal manner in patients with diabetes [54,55].

Two hypotheses involving glucagon to explain the hormonal dysregulation of plasma glucose in diabetes have gained particular support: the bihormonal and the glucagonocentric hypothesis. The glucagonocentric hypothesis [7] was recently greatly supported by several studies demonstrating that disruption of GCGR signaling (by genetic methods, i.e., knock-out of the GCGR, or by antibodies against the GCGR), normalizes hyperglycemia in animal models of Type 1 diabetes (mice, rats and monkeys) [56-59] and also improves glucose regula- 


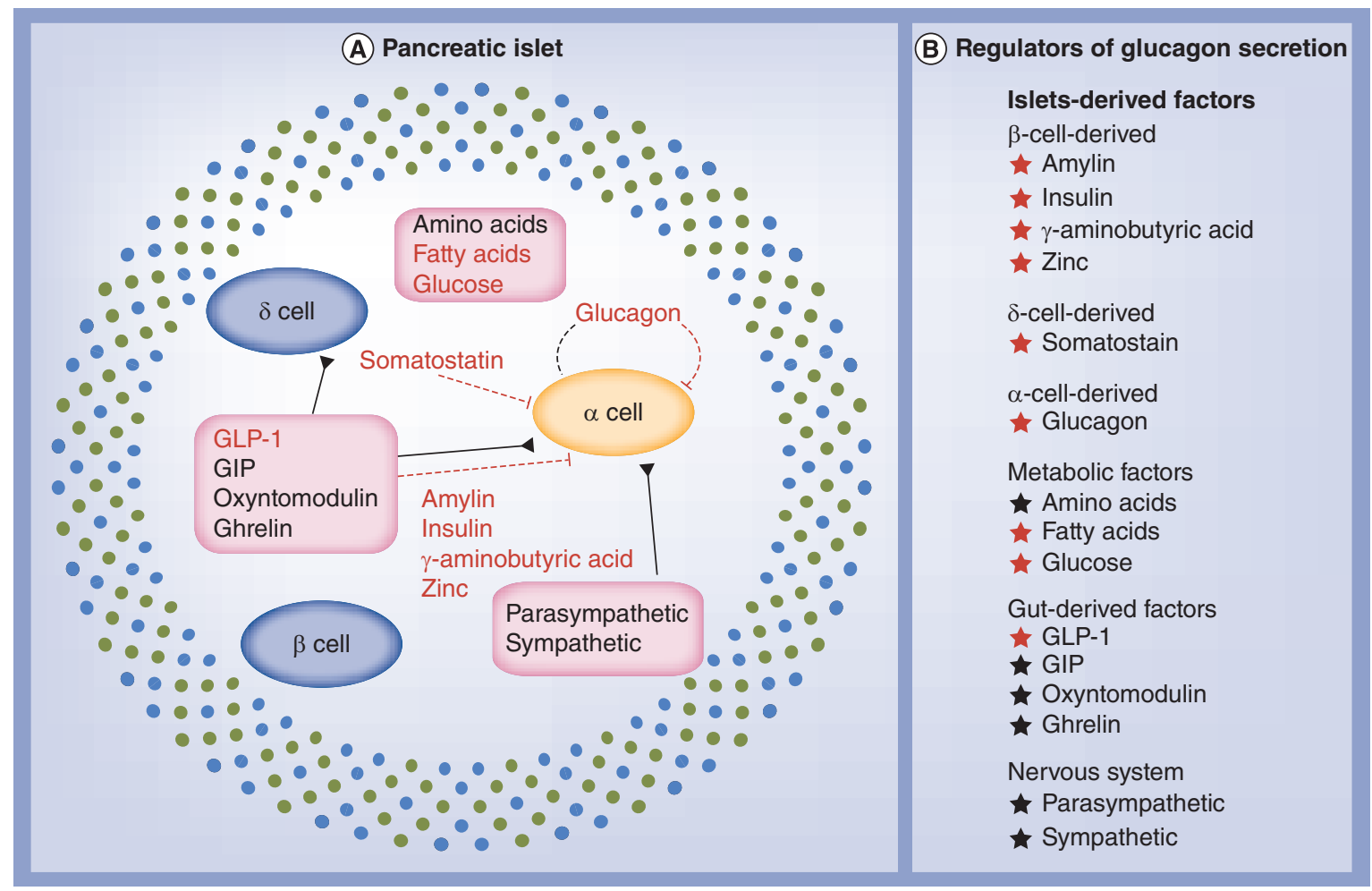

Figure 2. Regulation of glucagon secretion. (A) Several factors regulate the secretion of glucagon; most importantly glucose, amino acids, gastrointestinal peptides, the nervous system and possibly peptides secreted from the $\alpha, \beta$ and $\delta$ cells (intra-islet regulation), among which $\delta$-cell-derived somatostatin is well established.

(B) Same factors as in A are shown in red (inhibit secretion of glucagon) or black (stimulate secretion of glucagon).

tion in Type 2 diabetes [12]. However, acute glucagon deficiency produced by either acute $\alpha$ cell depletion, glucagon-immunoneutralization or pharmacological antagonism of the GCGR does not reduce the hyperglycemia of insulin deficiency [60]. The differences between studies involving chronic deletion or block of the GCGR and those relying on an acute block may be due to one of the important consequences of GCGR antagonism: $\alpha$ cell hypersecretion and hyperplasia [57,61,62]. The hyperplastic $\alpha$ cells seem to produce GLP-1 [61,63]. There may also be hyperplasia of the intestinal L-cells, resulting in further GLP-1 secretion. The mechanism whereby GLP-1 has glucose-lowering effects in animals incapable of glucagon signaling and insulin secretion is unclear, but Jun et al. recently showed that a mouse model of Type 1 diabetes defective in both GLP$1 R$ and GCGR exhibited increased hepatic glucose production [63], suggesting that GLP-1 might influence hepatic glucose production independently of its insulinotropic and glucagonostatic properties. In line with this, GLP-1 was recently claimed to influence hepatic glucose production in humans independent of changes in islet hormone secretion [64].

The extent to which $\alpha$-cell dysfunction (appearing as hyperglucagonemia) precedes a decline in insu- lin secretion in subjects with Type 2 diabetes is not known. In epidemiological studies, Ahrén et al. were able to demonstrate that incipient impairment of glucose tolerance was associated with attenuated insulininduced suppression of glucagon secretion [65]. Prospective data on plasma glucagon levels in subjects at risk of developing Type 2 diabetes (impaired glucose tolerance and impaired fasting glucose) similarly suggest that glucagon hypersecretion occurs very early in the development of glucose intolerance [51,66-68].

Hyperglucagonemia has also been found in patients with pancreatic neuroendocrine tumors [69]. Interestingly, the molecular heterogeneity of the circulating products of glucagon-producing tumors seems to reflect the clinical presentation [70]. For example greater than tenfold hypersecretion of glucagon (3485 MW) presents clinically as a classical glucagonoma syndrome with a characteristic dermatitis termed necrolytic migratory erythema [71] (which interestingly can be ameliorated by an infusion of amino acids [72], see below). In contrast, greater than tenfold elevations of plasma concentrations of glucagon-like immunoreactivity (GLI), representing the intestinal glucagon-containing proglucagon cleavage products oxyntomodulin and glicentin and which results from measurements using side-viewing anti- 
bodies, does not seem to correlate with the appearance of a classical glucagonoma syndrome. Thus, an 'L-cell like' cleavage (PC1) of the proglucagon in the tumor (Figure 1), which also resulted in extremely high levels of active GLP-1 $\left(7-36 \mathrm{NH}_{2}\right)$ was associated with hypoglycemia [73,74]. Finally, hyperglucagonemia due to $\mathrm{N}$-terminally elongated forms of the glucagon molecule may also be found in subjects with glucagonoma and, as aforementioned, in subjects with renal dysfunction [45]. However, further studies are needed to clarify the exact molecular nature and the source and activity of such $\mathrm{N}$-terminally elongated glucagon molecules.

\section{Hyperglucagonemia from a hepatic point of view}

Glucagon is secreted into the portal vein and from there it reaches the hepatocytes at a higher concentration compared with what can be found in the systemic circulation [75]. Glucagon increases blood glucose levels in a dose-dependent manner [76] by potent activation of hepatic glucose production, as demonstrated in a clamp study of conscious overnight-fasted dogs; net hepatic glucose output (NHGO), mainly derived from glycogenolysis, increased from $11 \mu \mathrm{mol} / \mathrm{kg} / \mathrm{min}$ to $36 \mu \mathrm{mol} / \mathrm{kg} / \mathrm{min}$ in $15 \mathrm{~min}$ following infusion with glucagon (Figure 3) [1]. Although glucagon secretion may show pulsatility [77], the effect of glucagon on the liver does not seem to depend on pulsatility [78]. Cyclic AMP/protein kinase A have long been established as the major intracellular mediators of the glucoregulatory effects of glucagon within hepatocytes by activation of glycogen phosphorylase, resulting in increased glycogenolysis [79]. Although glucagon importantly regulates enzymes responsible for gluconeogenesis, including PEPCK, glucagon may not be the most important regulator of gluconeogenic fluxes due to its inability to increase the delivery of gluconeogenic amino acids or glycerol to the liver in humans (because GCGRs do not appear to be expressed in skeletal muscle and in adipose tissue in humans [80]). During prolonged fasting glucagon may have importance for gluconeogenesis, not through mobilizing the precursors (which normally is taken care of by cortisol and low levels of insulin) needed for it, but rather by maintaining gluconeogenic enzymes in an optimal state. Importantly, dysfunction of the liver, as observed in nonalcoholic fatty liver disease and cirrhosis, appear to cause hypersecretion of glucagon independently of changes in glucose tolerance [81,82]. Is glucagon hypersecretion a direct cause of failed hepatic function, and if so, how does the liver signal to the pancreas? In the following, we will propose and discuss the existence of a pancreas-liver axis with glucagon and amino acid feedback loops.

\section{Knock-out of the glucagon receptor causes hyperglucagonemia, hyperplasia of pancreatic $\alpha$ cells \& hyperaminoacidemia}

A key discovery in glucagon biology was the cloning and characterization of the GCGR [83]. In humans, expression of the GCGR is mainly detected in the liver, the $\beta$ cells of the pancreas, the kidney, the small intestine, certain regions of the brain and the heart [84]. Intriguingly, disruption of glucagon signaling causes hyperglucagonemia and $\alpha$-cell hyperplasia, as demonstrated in both GCGR knock-out mouse $[60,61,85]$ and in humans, including those with dysfunctional mutations of the GCGR [86]. Also destruction of the glucagon gene leads to marked $\alpha$-cell hyperplasia [87]. Genetic deletion of the PC2 enzyme, which disrupts glucagon signaling by attenuating the processing of proglucagon to glucagon in pancreatic $\alpha$ cells thereby reducing plasma glucagon, also causes mild hypoglycemia and $\alpha$-cell hyperplasia, both of which can be reversed by provision of exogenous glucagon by osmotic micropumps [88]. Interest-

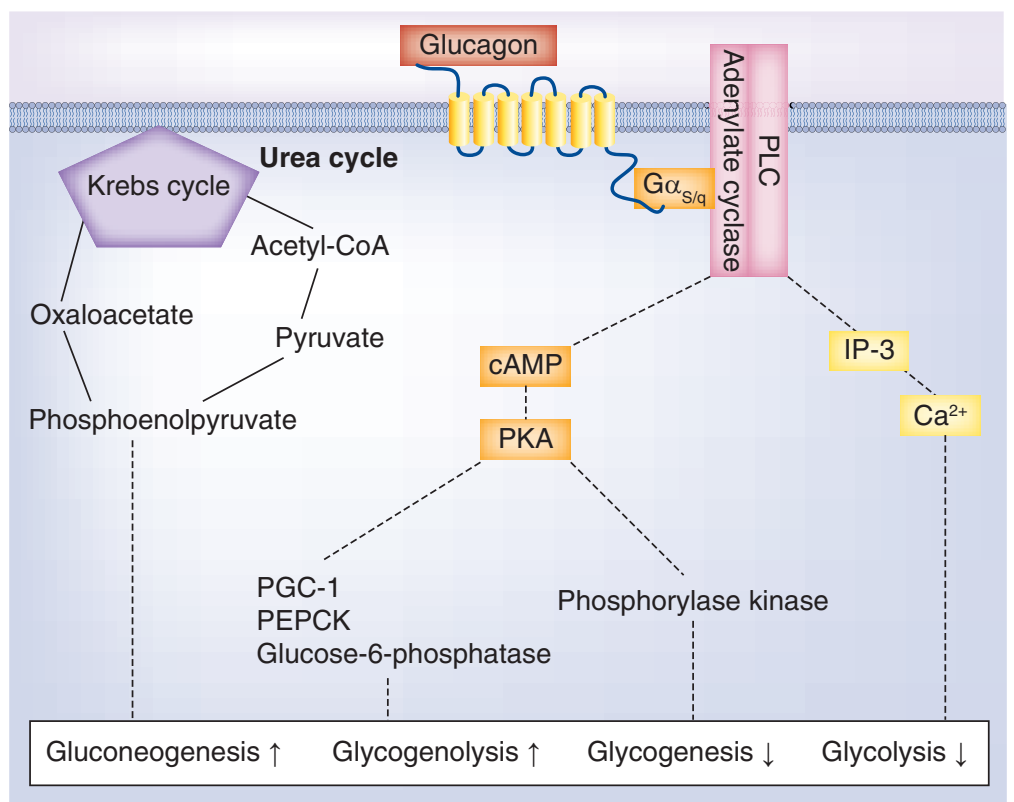

Figure 3. Molecular mechanisms for glucagon-stimulated gluconeogenesis in hepatocytes. Glucagon binds to its seven-transmembrane receptor on the hepatocyte and thereby activates Gas- and Gq-coupled pathways. PKA phosphorylates and thereby activates gluconeogenic enzymes, including PEPCK and glucose-6-phosphatase, which then increase gluconeogenesis and glycogenolysis. Phosphorylase kinase is a serine/threonine-specific protein kinase that activates glycogen phosphorylase which then releases glucose-1-phosphate from glycogen. Levels of intracellular calcium are important for the glucagon-induced inhibition of glycolysis. Catabolism of proteinogenic amino acids is depicted in the upper left. CAMP: Cyclic adenosine monophosphate. 


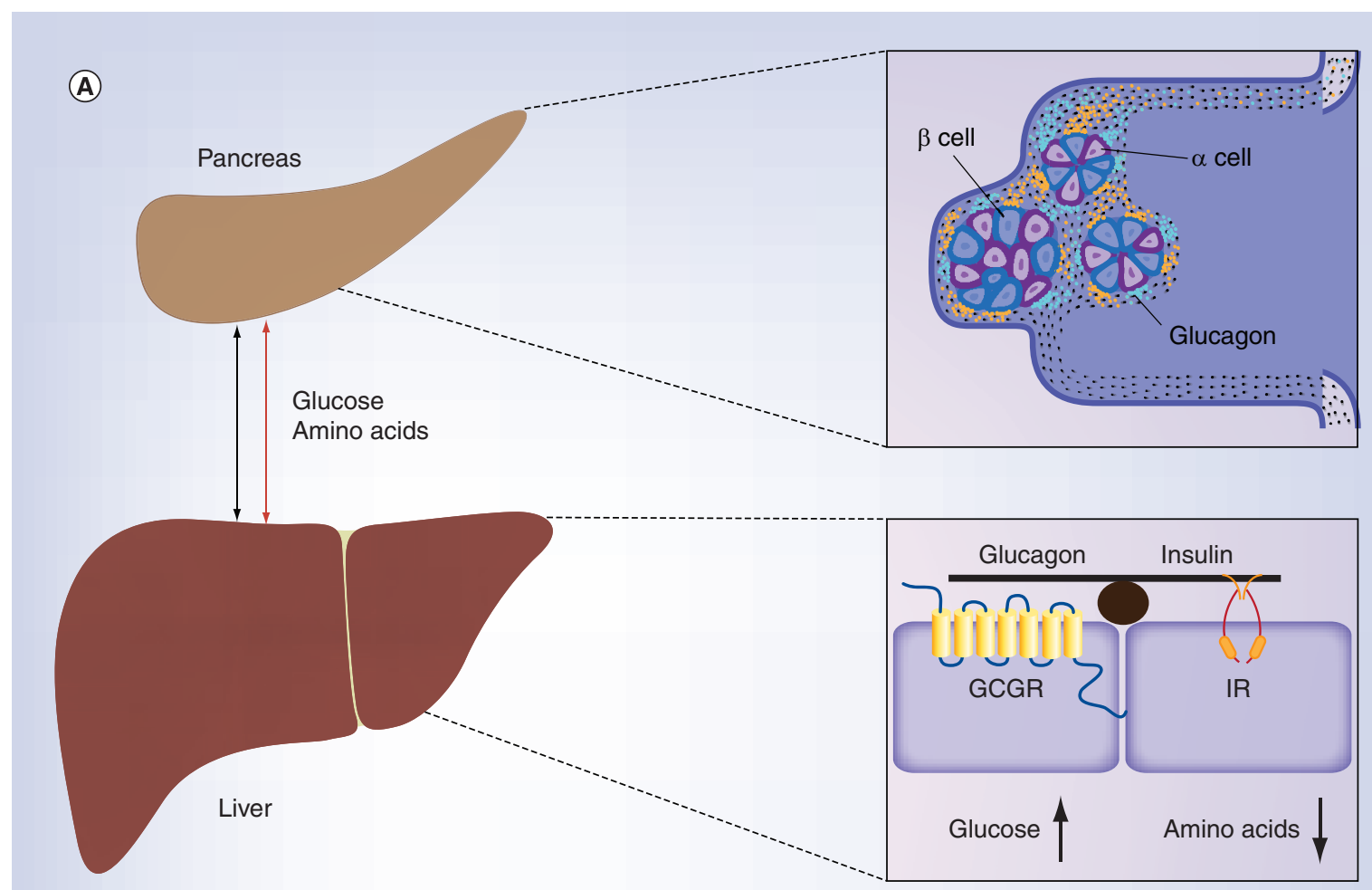

(B) Knock-out of the GCGR

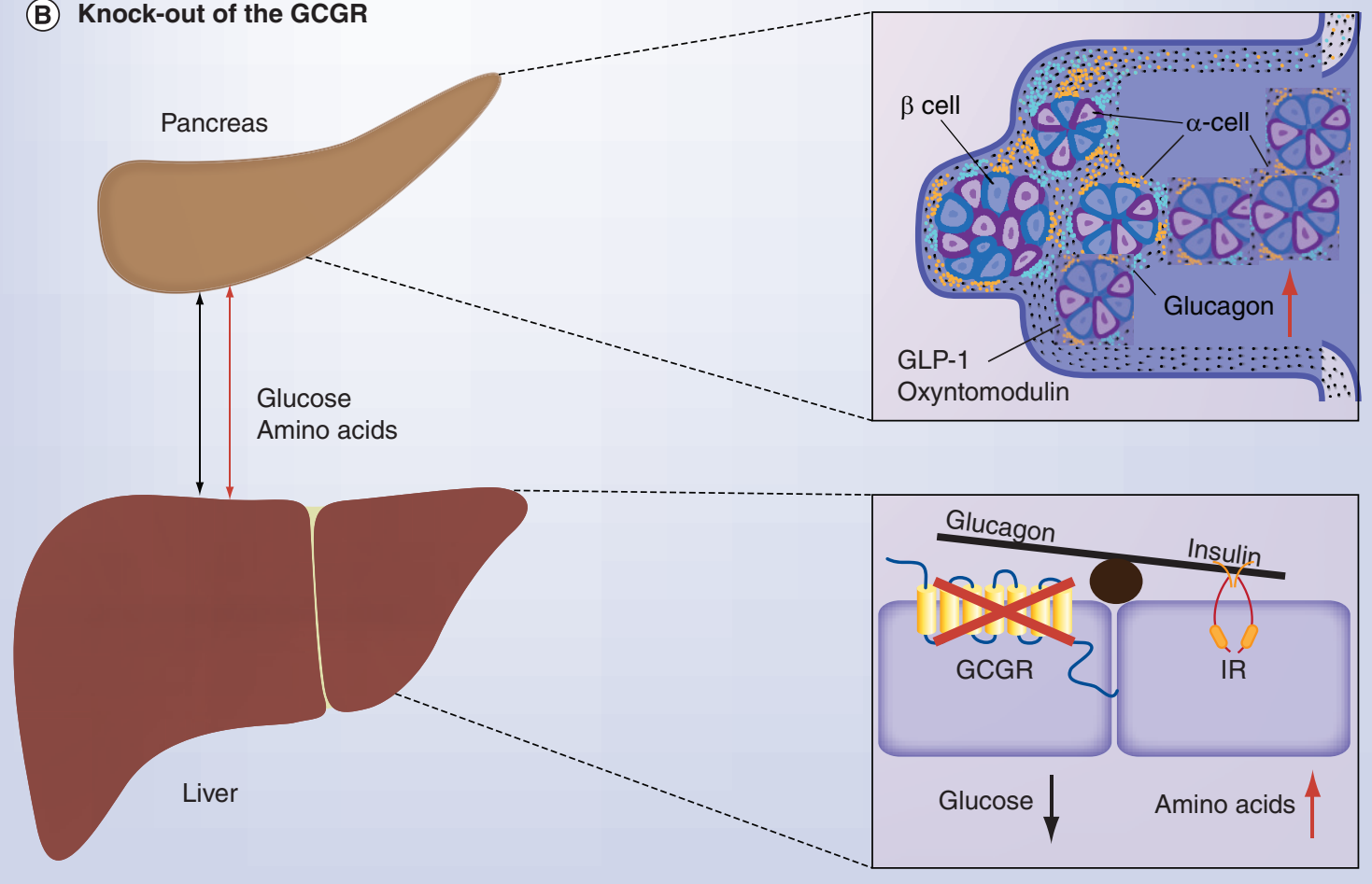

Figure 4. Metabolic effects of glucagon receptor uncoupling on the hepato-pancreas axis. (A) illustrates the effects of the normal balance between glucagon and insulin on the liver, and (B) illustrates that specific knock-out of liver GCGR causes hyperaminoacidemia, hypersecretion of glucagon (and potentially also other proglucagonderived peptides including bioactive GLP-1 and oxyntomodulin), and eventually hyperplasia of pancreatic $\alpha$ cells but not $\beta$ cells.

Data taken with permission from [30].

GCGR: Glucagon receptor. 
ingly, it has been reported that in some patients with glucagonoma (glucagon producing tumors) the levels of amino acids are very low [71] suggesting that at pathological levels of glucagon (up to several $\mathrm{nmol} / \mathrm{l}$ compared with $4-8 \mathrm{pmol} / \mathrm{L}$ in healthy subjects) may cause the liver to suck in amino acids for conversion to urea, thereby causing severe hypoaminoacidemia. It is well established that glucagon is a powerful regulator of hepatic ureagenesis from amino acids and that glucagon immunoneutralization blocks this process [89]. Furthermore, $\mathrm{N}$-acetylglutamate synthase (NAGS) that produces $\mathrm{N}$-acetyl glutamate a unique co-factor essential for catalyzing the first enzyme urea genesis carbomyl phosphate synthetase-1 seems to be regulated at a transcriptional level by glucagon [90], in addition, several enzymes in the urea cycle are regulated at a transcriptional level by glucagon [91]. Thus it seems clear that glucagon is a major regulator of plasma amino acid levels. But what is the role of amino acids for $\alpha$-cell biology and secretion? Regarding the $\alpha$-cell hyperplasia after glucagon receptor deletion it was soon demonstrated that liver-specific deletion of the GCGR also causes $\alpha$-cell hyperplasia [62], and that $\alpha$-cell hyperplasia in islets from GCGR knock-out mice normalizes following 8 weeks of implantation of the hyperplastic islets into wild-type mice [62], suggesting that the hyperplasia was caused by a humoral liver-derived $\alpha$-cell growth factor. Further studies revealed that disruption of glucagon signaling by proglucagon gene deletion is associated with hyperaminoacidemia [14,92], and in a recent study it was demonstrated that experimental hyperaminoacidemia may cause $\alpha$-cell hyperplasia [14]. Collectively, these studies suggest that we might need to rethink the role of glucagon as exclusively associated with glucose metabolism and that amino acid are the missing link in a feedback loop connecting the liver and the $\alpha$ cells (Figure 4). Thus, it seems that a new era of glucagon biology has just started.

\section{Conclusion}

Glucagon biology has been studied for decades, but the mechanisms regulating glucagon secretion and its impact on diseases such as diabetes remain debated. Accurate estimation of plasma glucagon levels is important for unraveling the importance of elevated levels in diabetes and other pathological conditions and has been challenging, but improved methods are now appearing. Emerging data suggest that the physiological role of glucagon is not restricted to blood glucose regulation, but also encompasses amino acid metabolism. Thus, a liver- $\alpha$-cell axis seems to exist where glucagon regulates hepatic amino acid turn over and amino acids regulate $\alpha$-cell growth and secretion. This may explain that conditions of glucagon excess and deficiency have greater impact on amino acid metabolism than on glucose metabolism while deficiencies of amino acid metabolism, including liver disease, may have greater impact on $\alpha$-cell secretion than disturbances of glucose metabolism.

\section{Future perspective}

Knowledge about the exact mechanisms whereby glucagon secretion is regulated is important for the understanding of diabetes pathophysiology. Hyperglucagonemia, which can now be diagnosed with greater certainty because of the development of new improved assay methods [45], may not only reflect the dysregulation of glucose homeostasis; rather, supported by recent evidence $[14,62,92]$, it may be part of a hepatopancreatic feedback system. Thus, factors that uncouple this feedback systemic (liver disease, diabetes, GCGR

\section{Executive summary}

\section{The measurement of glucagon is tricky but crucial for understanding the biology of glucagon}

- The development of specific and sensitive methods for measurement of glucagon is crucial for understanding the biology of glucagon. For instance, application of highly specific sandwich ELISAs for estimating glucagon secretion is important in patients with kidney failure and for the correct classification of tumors producing glucagon.

\section{Hyperglucagonemia from a hepatic point of view}

- Hyperglucagonemia may reflect inappropriate negative feedback by a humoral hepatic factor: the paradoxical hypersecretion in subjects with Type 2 diabetes may not only be due to dysregulation of glucose levels and 'miscommunication' within the pancreatic islets, but may reflect impaired glucagon signaling in the liver. Liverspecific deletion of the glucagon receptor causes $\alpha$-cell hyperplasia and elevated plasma levels of glucagon.

Knock-out of the glucagon receptor causes hyperglucagonemia, hyperplasia of pancreatic $\alpha$ cells and hyperaminoacidemia

- Amino acids may be crucial for a hitherto unknown hepatic-pancreas feedback system controlling $\alpha$-cell numbers and function. Conversely glucagon levels importantly regulate amino acid levels and turnover. Knock-out of the glucagon receptor causes hyperglucagonemia, hyperplasia of pancreatic $\alpha$ cells and hyperaminoacidemia, and there is evidence to suggest that it is the hyperaminoacidemia that causes the hypersecretion and hyperplasia. 
antagonists) result in a compensatory hypersecretion of $\alpha$-cell-derived glucagon. In addition, it has been demonstrated that postprandial glucagon responses may be derived from the GI tract. This raises new important aspect of glucagon physiology and pathophysiology maybe glucagon from the gut is more important for amino acid regulation than for glucose metabolism.

We suggest that a new era with a reappraisal of glucagon from its current position as a mainly glucoregulatory hormone to an amino acid regulatory hormone will emerge in the coming years. This also suggests that hyperglucagonemia whenever it occurs should be re-evaluated in relation to liver function and amino acid turnover. There are already indications that the hyperglucagonemia of Type 2 diabetes may indeed reflect early hepatic dysfunction [93]. Recognition of the new liver- $\alpha$-cell feedback loop may therefore have major impact on our understanding of the

\section{References}

Papers of special note have been highlighted as:

- of interest; $\bullet$ of considerable interest

1 Ramnanan CJ, Edgerton DS, Kraft G, Cherrington AD. Physiologic action of glucagon on liver glucose metabolism. Diabetes Obes. Metabol. 13, 118-125 (2011).

2 Raskin P, Unger RH. Hyperglucagonemia and its suppression. N. Engl. J. Med. 299(9), 433-436 (1978).

3 Perley MJ, Kipnis DM. Plasma insulin responses to oral and intravenous glucose: studies in normal and diabetic subjects. J. Clin. Invest. 46(12), 1954-1962 (1967).

4 Kimball CP, Murlin JR. Aqueous extracts of pancreas: III. Some precipitation reactions of insulin. J. Biol. Chem. 58(1), 337-346 (1923).

5 Cherrington A, Vranic M. Role of glucagon and insulin in control of glucose turnover. Metabolism 20(6), 625-628 (1971).

6 Berson SA, Yalow RS, Bauman A, Rothschild MA, Newerly K. Insulin- ${ }^{131}$ metabolism in human subjects: demonstration of insulin binding globulin in the circulation of insulin treated subjects. J. Clin. Invest. 35(2), 170-190 (1956).

7 Unger RH, Cherrington AD. Glucagonocentric restructuring of diabetes: a pathophysiologic and therapeutic makeover. J. Clin. Invest. 122(1), 4-12 (2012).

- An essential review on the glucagonocentric hypothesis by Professor Unger.

8 Cherrington AD, Liljenquist JE, Shulman GI, Williams PE, Lacy WW. Importance of hypoglycemia-induced glucose production during isolated glucagon deficiency. Am. J. Physiol. 236(3), E263-E271 (1979).

9 Holst JJ, Madsen OG, Knop J, Schmidt A. The effect of intraportal and peripheral infusions of glucagon on insulin and glucose concentrations and glucose tolerance in normal man. Diabetologia 13(5), 487-490 (1977).

10 Brand CL, Jørgensen PN, Svendsen I, Hoist JJ. Evidence for a major role for glucagon in regulation of plasma glucose in paradox hypersecretion of glucagon in subjects with Type 2 diabetes and improve our understanding of basic glucagon biology.

\section{Financial \& competing interests disclosure}

The authors have no relevant affiliations or financial involvement with any organization or entity with a financial interest in or financial conflict with the subject matter or materials discussed in the manuscript. This includes employment, consultancies, honoraria, stock ownership or options, expert testimony, grants or patents received or pending, or royalties.

No writing assistance was utilized in the production of this manuscript.

\section{Open access}

This work is licensed under the Attribution-NonCommercialNoDerivatives 4.0 Unported License. To view a copy of this license, visit http://creativecommons.org/licenses/by-nc-nd/4.0/

conscious, nondiabetic, and alloxan-induced diabetic rabbits. Diabetes 45(8), 1076-1083 (1996).

11 Banting FG, Best CH, Collip JB, Campbell WR, Fletcher AA. Pancreatic extracts in the treatment of diabetes mellitus. Can. Med. Assoc. J. 12(3), 141-146 (1922).

12 Kazda CM, Garhyan P, Kelly RP et al. A randomized, double-blind, placebo-controlled Phase 2 study of the glucagon receptor antagonist LY2409021 in patients with Type 2 diabetes. Diabetes Care doi:10.2337/dc15-1643 (2015) (Epub ahead of print).

13 Bagger JI, Knop FK, Holst JJ, Vilsboll T. Glucagon antagonism as a potential therapeutic target in Type 2 diabetes. Diabetes Obes. Metab. 13(11), 965-971 (2011).

14 Solloway MJ, Madjidi A, Gu C et al. Glucagon couples hepatic amino acid catabolism to mTOR-dependent regulation of $\alpha$-cell mass. Cell Rep. 12(3), 495-510 (2015).

-. The first paper that identified amino acids as potential regulators of $\alpha$-cell survival and function.

15 Olofsson CS, Salehi A, Gopel SO, Holm C, Rorsman P. Palmitate stimulation of glucagon secretion in mouse pancreatic alpha-cells results from activation of L-type calcium channels and elevation of cytoplasmic calcium. Diabetes 53(11), 2836-2843 (2004).

16 Wettergren A, Schjoldager B, Mortensen PE, Myhre J, Christiansen J, Holst JJ. Truncated GLP-1 (proglucagon 78-107-amide) inhibits gastric and pancreatic functions in man. Dig. Dis. Sci. 38(4), 665-673 (1993).

17 Baldissera FG, Holst JJ, Knuhtsen S, Hilsted L, Nielsen OV. Oxyntomodulin (glicentin-[33-69]): pharmacokinetics, binding to liver cell membranes, effects on isolated perfused pig pancreas, and secretion from isolated perfused lower small intestine of pigs. Regul. Pept. 21(1-2), 151-166 (1988).

18 Meier JJ, Gallwitz B, Siepmann N et al. Gastric inhibitory polypeptide (GIP) dose-dependently stimulates glucagon secretion in healthy human subjects at euglycemia. Diabetologia 46(6), 798-801 (2003). 
19 Christensen M, Vedtofte L, Holst JJ, Vilsboll T, Knop FK. Glucose-dependent insulinotropic polypeptide: a bifunctional glucose-dependent regulator of glucagon and insulin secretion in humans. Diabetes 60 (12), 3103-3109 (2011).

20 Holst JJ, Schwartz TW, Knuhtsen S, Jensen SL, Nielsen OV. Autonomic nervous control of the endocrine secretion from the isolated, perfused pig pancreas. J. Auton. Nerv. Syst. 17(1), 71-84 (1986).

21 Holst JJ, Christensen M, Lund A et al. Regulation of glucagon secretion by incretins. Diabetes Obes. Metab. 13(Suppl. 1), 89-94 (2011).

22 Hare KJ, Vilsboll T, Asmar M, Deacon CF, Knop FK, Holst JJ. The glucagonostatic and insulinotropic effects of glucagon-like peptide 1 contribute equally to its glucoselowering action. Diabetes 59(7), 1765-1770 (2010).

23 Wang Q, Liang X, Wang S. Intra-islet glucagon secretion and action in the regulation of glucose homeostasis. Front. Physiol. 3485 (2012).

24 Gromada J, Franklin I, Wollheim CB. $\alpha$-cells of the endocrine pancreas: 35 years of research but the enigma remains. Endocr. Rev. 28(1), 84-116 (2007).

25 Kieffer TJ, Heller RS, Unson CG, Weir GC, Habener JF. Distribution of glucagon receptors on hormone-specific endocrine cells of rat pancreatic islets. Endocrinology 137(11), 5119-5125 (1996).

26 Cooperberg BA, Cryer PE. Insulin reciprocally regulates glucagon secretion in humans. Diabetes 59(11), 2936-2940 (2010).

27 Kawamori D, Kurpad AJ, Hu J et al. Insulin signaling in alpha cells modulates glucagon secretion in vivo. Cell Metab. 9(4), 350-361 (2009).

28 Moens K, Heimberg H, Flamez D et al. Expression and functional activity of glucagon, glucagon-like peptide I, and glucose-dependent insulinotropic peptide receptors in rat pancreatic islet cells. Diabetes 45(2), 257-261 (1996).

29 Moens K, Flamez D, Schravendijk CV, Ling Z, Pipeleers $\mathrm{D}$, Schuit F. Dual glucagon recognition by pancreatic $\beta$-cells via glucagon and glucagon-like peptide 1 receptors. Diabetes 47(1), 66-72 (1998).

30 Wewer Albrechtsen NJ, Hornburg D, Albrechtsen R et al. Oxyntomodulin identified as a marker of Type 2 diabetes and gastric bypass surgery by mass-spectrometry based profiling of human plasma. EBioMedicine doi:10.1016/j. ebiom.2016.03.034 (2016) (Epub ahead of print).

31 Campbell JE, Drucker DJ. Islet $\alpha$ cells and glucagon - critical regulators of energy homeostasis. Nat. Rev. Endocrinol. 11(6), 329-338 (2015).

32 Habegger KM, Stemmer K, Cheng C et al. Fibroblast growth factor 21 mediates specific glucagon actions. Diabetes 62(5), 1453-1463 (2013).

33 Von Holstein-Rathlou S, Bondurant LD, Peltekian L et al. FGF21 mediates endocrine control of simple sugar intake and sweet taste preference by the liver. Cell Metab. 23(2), 335-343 (2016).

34 Tan BK, Hallschmid M, Adya R, Kern W, Lehnert H, Randeva HS. Fibroblast growth factor 21 (FGF21) in human cerebrospinal fluid: relationship with plasma FGF21 and body adiposity. Diabetes 60 (11), 2758-2762 (2011).

35 Mery P-F, Brechler V, Pavoine C, Pecker F, Fischmeister R. Glucagon stimulates the cardiac $\mathrm{Ca}^{2+}$ current by activation of adenylyl cyclase and inhibition of phosphodiesterase. Nature 345(6271), 158-161 (1990).

Mochiki E, Suzuki H, Takenoshita S et al. Mechanism of inhibitory effect of glucagon on gastrointestinal motility and cause of side effects of glucagon. J. Gastroenterol. 33(6), 835-841 (1998).

37 Brereton MF, Vergari E, Zhang Q, Clark A. Alpha-, deltaand PP-cells: are they the architectural cornerstones of islet structure and co-ordination? J. Histochem. Cytochem. 63(8), 575-591 (2015).

38 Sandoval DA, D’alessio DA. Physiology of proglucagon peptides: role of glucagon and GLP-1 in health and disease. Physiol. Rev. 95(2), 513-548 (2015).

39 Bak MJ, Albrechtsen NW, Pedersen J et al. Specificity and sensitivity of commercially available assays for glucagon and oxyntomodulin measurement in humans. Eur. J. Endocrinol. $170(4), 529-538$ (2014).

40 Chesher D. Evaluating assay precision. Clin. Biochem. Rev. 29(Suppl. 1), S23-S26 (2008).

41 Holst JJ, Pedersen JH, Baldissera F, Stadil F. Circulating glucagon after total pancreatectomy in man. Diabetologia 25 (5), 396-399 (1983).

42 Muller WA, Girardier L, Seydoux J, Berger M, Renold AE, Vranic M. Extrapancreatic glucagon and glucagonlike immunoreactivity in depancreatized dogs: a quantitative assessment of secretion rates and anatomical delineation of sources. J. Clin. Invest. 62(1), 124-132 (1978).

43 Lund A, Bagger JI, Wewer Albrechtsen NJ et al. Evidence of extrapancreatic glucagon secretion in man. Diabetes 65(3), 585-597 (2015).

44 Holst JJ. Extrapancreatic glucagons. Digestion 17(2), 168-190 (1978).

45 Wewer Albrechtsen N, Hartmann B, Veedfald S et al. Hyperglucagonaemia analysed by glucagon sandwich ELISA: nonspecific interference or truly elevated levels? Diabetologia 57(9), 1919-1926 (2014).

46 Bak MJ, Albrechtsen NW, Hartmann B et al. Effect of aprotinin (Trasylol ${ }^{\mathrm{TM}}$ ) on degradation of exogenous and endogenous glucagon in human, mouse and rat plasma. J. Endocrinol. Diabetes 1(1), 5 (2014).

47 Wewer Albrechtsen NJ, Veedfald S, Plamboeck A et al. Inability of some commercial assays to measure suppression of glucagon secretion. J. Diabetes Res. 2016, 5 (2016).

Wewer Albrechtsen NJ, Bak MJ, Hartmann B et al. Stability of glucagon-like peptide-1 and glucagon in human plasma. Endocr. Connect. 4(1), 50-57 (2015).

49 Reaven GM, Chen Y-DI, Golay A, Swislocki ALM, Jaspan JB. Documentation of hyperglucagonemia throughout the day in nonobese and obese patients with noninsulindependent diabetes mellitus. J. Clin. Endocrinol. Metabol. 64(1), 106-110 (1987). 
50 Unger RH, Aguilar-Parada E, Müller WA, Eisentraut AM. Studies of pancreatic alpha cell function in normal and diabetic subjects. J. Clin. Invest. 49(4), 837-848 (1970).

51 Knop FK, Aaboe K, Vilsboll T et al. Impaired incretin effect and fasting hyperglucagonaemia characterizing Type 2 diabetic subjects are early signs of dysmetabolism in obesity. Diabetes Obes. Metab. 14(6), 500-510 (2012).

52 Mitrakou A, Kelley D, Mokan M et al. Role of reduced suppression of glucose production and diminished early insulin release in impaired glucose tolerance. N. Engl. J. Med. 326(1), 22-29 (1992).

53 Moon JS, Won KC. Pancreatic $\alpha$-cell dysfunction in Type 2 diabetes: old kids on the block. Diabetes Metab. J. 39(1), 1-9 (2015).

54 Knop FK, Vilsbøll T, Madsbad S, Holst JJ, Krarup T. Inappropriate suppression of glucagon during OGTT but not during isoglycaemic i.v. glucose infusion contributes to the reduced incretin effect in Type 2 diabetes mellitus. Diabetologia 50(4), 797-805 (2007).

55 Hare KJ, Vilsboll T, Holst JJ, Knop FK. Inappropriate glucagon response after oral compared with isoglycemic intravenous glucose administration in patients with Type 1 diabetes. Am. J. Physiol. Endocrinol. Metab. 298(4), E832-E837 (2010).

56 Wang M-Y, Yan H, Shi Z et al. Glucagon receptor antibody completely suppresses Type 1 diabetes phenotype without insulin by disrupting a novel diabetogenic pathway. Proc. Natl Acad. Sci. USA 112(8), 2503-2508 (2015).

57 Lee Y, Wang M-Y, Du XQ, Charron MJ, Unger RH. Glucagon receptor knockout prevents insulin-deficient Type 1 diabetes in mice. Diabetes 60 (2), 391-397 (2011).

58 Brand CL, Rolin B, Jorgensen PN, Svendsen I, Kristensen JS, Holst JJ. Immunoneutralization of endogenous glucagon with monoclonal glucagon antibody normalizes hyperglycaemia in moderately streptozotocin-diabetic rats. Diabetologia 37(10), 985-993 (1994).

59 Okamoto H, Kim J, Aglione J et al. Glucagon receptor blockade with a human antibody normalizes blood glucose in diabetic mice and monkeys. Endocrinology 156(8), 2781-2794 (2015).

60 Steenberg VR, Jensen SM, Pedersen J et al. Acute disruption of glucagon secretion or action does not improve glucose tolerance in an insulin-deficient mouse model of diabetes. Diabetologia 59(2), 363-370 (2015).

61 Gelling RW, Du XQ, Dichmann DS et al. Lower blood glucose, hyperglucagonemia, and pancreatic $\alpha$ cell hyperplasia in glucagon receptor knockout mice. Proc. Natl Acad. Sci. USA 100 (3), 1438-1443 (2003).

62 Longuet C, Robledo AM, Dean ED et al. Liver-specific disruption of the murine glucagon receptor produces $\alpha$-cell hyperplasia: evidence for a circulating $\alpha$-cell growth factor. Diabetes 62(4), 1196-1205 (2012).

63 Jun LS, Millican RL, Hawkins ED et al. Absence of glucagon and insulin action reveals a role for the GLP-1 receptor in endogenous glucose production. Diabetes 64(3), 819-827 (2015).
64 Ferrannini E, Muscelli E, Frascerra S et al. Metabolic response to sodium-glucose cotransporter 2 inhibition in Type 2 diabetic patients. J. Clin. Invest. 124(2), 499-508

65 Ahrén B, Larsson H. Impaired glucose tolerance (IGT) is associated with reduced insulin-induced suppression of glucagon concentrations. Diabetologia 44(11), 1998-2003

66 Faerch K, Vaag A, Holst JJ, Hansen T, Jorgensen T, BorchJohnsen K. Natural history of insulin sensitivity and insulin secretion in the progression from normal glucose tolerance to impaired fasting glycemia and impaired glucose tolerance: the Inter99 study. Diabetes Care 32 (3), 439-444 (2009).

67 Jamison RA, Stark R, Dong J et al. Hyperglucagonemia precedes a decline in insulin secretion and causes hyperglycemia in chronically glucose-infused rats. Am. J. Physiol. 301(6), E1174-E1183 (2011).

68 Song W-J, Mondal P, Wolfe A et al. Glucagon regulates hepatic kisspeptin to impair insulin secretion. Cell Metab. 19(4), 667-681 (2014).

69 Wewer Albrechtsen NJ, Challis B, Damjanov I, Holst JJ. Do glucagonomas always produce glucagon? Bosn. J. Basic Med. Sci. 16(1), 1-7 (2016).

70 Holst JJ. Molecular heterogeneity of glucagon in normal subjects and in patients with glucagon-producing tumours. Diabetologia 24(5), 359-365 (1983).

71 Challis BG, Albrechtsen NJW, Bansiya V et al. Heterogeneity of glucagonomas due to differential processing of proglucagon-derived peptides. Endocrinol. Diabetes Metabol. Case Rep. 2015, 150105 (2015).

72 Alexander EK, Robinson M, Staniec M, Dluhy RG. Peripheral amino acid and fatty acid infusion for the treatment of necrolytic migratory erythema in the glucagonoma syndrome. Clin. Endocrinol. (Oxf.) 57(6), 827-831 (2002).

73 Guimarães M, Rodrigues P, Pereira SS et al. GLP1 and glucagon co-secreting pancreatic neuroendocrine tumor presenting as hypoglycemia after gastric bypass. Endocrinol. Diabetes Metabol. Case Rep. 2015, 150049 (2015).

74 Toft-Nielsen M, Madsbad S, Holst JJ. Exaggerated secretion of glucagon-like peptide-1 (GLP-1) could cause reactive hypoglycaemia. Diabetologia 41(10), 1180-1186 (1998).

75 Taborsky GJ Jr. The physiology of glucagon. J. Diabetes Sci. Technol. 4(6), 1338-1344 (2010).

76 Blauw H, Wendl I, Devries JH, Heise T, Jax T. Pharmacokinetics and pharmacodynamics of various glucagon dosages at different blood glucose levels. Diabetes Obes. Metab. 18(1), 34-39 (2016).

77 Rohrer S, Menge BA, Grüber L et al. Impaired crosstalk between pulsatile insulin and glucagon secretion in prediabetic individuals. J. Clin. Endocrinol. Metabol. 97(5), E791-E795 (2012).

78 Dobbins RL, Davis SN, Neal DW, Cobelli C, Cherrington AD. Pulsatility does not alter the response to a physiological increment in glucagon in the conscious dog. Am. J. Physiol. 266(3 Pt 1), E467-E478 (1994).

79 Rivera N, Ramnanan CJ, An Z et al. Insulin-induced hypoglycemia increases hepatic sensitivity to glucagon in dogs. J. Clin. Invest. 120 (12), 4425-4435 (2010). 
Livingston JN, Einarsson K, Backman L, Ewerth S, Arner P. Glucagon receptor of human liver. Studies of its molecular weight and binding properties, and its ability to activate hepatic adenylyl cyclase of non-obese and obese subjects. J. Clin. Invest. 75(2), 397-403 (1985).

81 Raddatz D, Roßbach C, Buchwald A, Scholz KH, Ramadori G, Nolte W. Fasting hyperglucagonemia in patients with transjugular intrahepatic portosystemic shunts (TIPS). Exp. Clin. Endocrinol. Diabetes 113(05), 268-274 (2005).

82 McDonald TJ, Dupre J, Caussignac Y, Radziuk J, Van Vliet $S$. Hyperglucagonemia in liver cirrhosis with portal-systemic venous anastomoses: responses of plasma glucagon and gastric inhibitory polypeptide to oral or intravenous glucose in cirrhotics with normal or elevated fasting plasma glucose levels. Metabolism 28(4), 300-307 (1979).

83 Jelinek LJ, Lok S, Rosenberg GB et al. Expression cloning and signaling properties of the rat glucagon receptor. Science 259(5101), 1614-1616 (1993).

84 Dunphy JL, Taylor RG, Fuller PJ. Tissue distribution of rat glucagon receptor and GLP-1 receptor gene expression. Mol. Cell. Endocrinol. 141(1-2), 179-186 (1998).

85 Parker JC, Andrews KM, Allen MR, Stock JL, McNeish JD. Glycemic control in mice with targeted disruption of the glucagon receptor gene. Biochem. Biophys. Res. Commun. 290(2), 839-843 (2002).

86 Sipos B, Sperveslage J, Anlauf M et al. Glucagon cell hyperplasia and neoplasia with and without glucagon receptor mutations. J. Clin. Endocrinol. Metabol. 100(5), E783-E788 (2015).

87

Hayashi Y, Yamamoto M, Mizoguchi H et al. Mice deficient for glucagon gene-derived peptides display normoglycemia and hyperplasia of islet \{alpha\}-cells but not of intestinal L-cells. Mol. Endocrinol. 23(12), 1990-1999 (2009).

88 Webb GC, Akbar MS, Zhao C, Swift HH, Steiner DF Glucagon replacement via micro-osmotic pump corrects hypoglycemia and $\alpha$-cell hyperplasia in prohormone convertase 2 knockout mice. Diabetes 51(2), 398-405 (2002).

89 Almdal TP, Holst JJ, Heindorff H, Vilstrup H. Glucagon immunoneutralization in diabetic rats normalizes urea synthesis and decreases nitrogen wasting. Diabetes 41(1), 12-16 (1992).

90 Heibel SK, Lopez GY, Panglao M et al. Transcriptional regulation of $\mathrm{N}$-acetylglutamate synthase. PLoS ONE 7(2), e29527 (2012).

91 Takiguchi M, Mori M. Transcriptional regulation of genes for ornithine cycle enzymes. Biochem. J. 312(Pt 3), 649-659 (1995).

92 Watanabe C, Seino Y, Miyahira $\mathrm{H}$ et al. Remodeling of hepatic metabolism and hyperaminoacidemia in mice deficient in proglucagon-derived peptides. Diabetes 61(1), 74-84 (2012).

93 Junker AE, Gluud L, Holst JJ, Knop FK, Vilsboll T. Diabetic and nondiabetic patients with nonalcoholic fatty liver disease have an impaired incretin effect and fasting hyperglucagonaemia. J. Intern. Med. 279(5), 485-493 (2016).

- Hyperglucagonemia identified in subjects with fatty liver disease independent of glycemic index supporting the concept of a glucagon feedback loop between the liver and pancreas. 